\title{
Bimodality and the genetics of milk flow traits in the Italian Holstein-Friesian breed
}

\author{
A. B. Samoré, ${ }^{* 1}$ S. I. Román-Ponce, ${ }^{*} \dagger$ F. Vacirca, ${ }^{*} E$. Frigo, ${ }^{*}$ F. Canavesi, $\ddagger$ A. Bagnato, ${ }^{*}$ and C. Maltecca§ \\ *Università degli Studi di Milano, Dipartimento di Scienze e Tecnologie Veterinarie per la Sicurezza Alimentare, via D. Trentacoste 2, \\ 20133 Milan, Italy \\ †Instituto Nacional de Investigaciones Forestales Agricolas y Pecuarias, Campo Experimental Valles Centrales - CIRPAS, 68200, \\ Oaxaca, México \\ $\ddagger$ Associazione Nazionale Allevatori Frisona Italiana, Via Bergamo, 292 (loc. Migliaro), 26100 Cremona, Italy \\ §Department of Animal Science, North Carolina State University, Box 7621, Raleigh 27695
}

\section{ABSTRACT}

The overall goal of this study was to investigate milk flow traits in Italian Holstein-Friesian cows and, in particular, the bimodality of milk flow, defined as delayed milk ejection at the start of milking. Using a milkometer, 2,886 records were collected from 133 herds in northern Italy from 2001 to 2007. All records included 5 time-period measurements for milk flow, somatic cell score (SCS), milk yield, 8 udder type traits, and the presence or absence of bimodality in milk flow. Genetic parameters were estimated using linear animal models for continuous traits such as milk flow, udder type, SCS, and milk production, whereas bimodality was analyzed as a categorical trait. With the exception of decreasing time (which had a very small heritability value of 0.06 ), heritability values for milk flow traits were moderate, ranging from 0.10 (ascending time) to 0.41 (maximum milk flow). In addition, moderate to high genetic correlations were estimated between total milking time and other time measures (from 0.78 to 0.87 ), and among time flow traits (from 0.62 to 0.91 ). The decreasing time was the trait most genetically correlated with udder type traits, with correlation values of 0.92 with rear udder height, 0.85 with rear udder width, and 0.73 with teat placement. Large udders with strong attachments were also associated with greater milk production. Heritability estimated for bimodality was 0.43 , and its genetic correlation with milk flow traits and SCS indicated a sizable genetic component underlying this trait. Bimodality was negatively associated with milk production; shorter milking times and greater peak milk levels were genetically correlated with more frequent bimodal flows, indicating that faster milk release would result in an increase in bimodal patterns. The negative genetic correlation of bimodality

Received July 9, 2010.

Accepted February 16, 2011.

${ }^{1}$ Corresponding author: antonia.samore@unimi.it with SCS $(-0.30)$ and the genetic correlation between milk flow traits and SCS suggest that the relationship between milkability and SCS is probably nonlinear and that intermediate flow rates are optimal with respect to mastitis susceptibility. Quicker milk flow over a shorter period would increase the frequency of bimodal curves in milking, whereas the correlation between bimodality and both ascending and descending time was less clear. Key words: bimodality, milk flow, Holstein-Friesian cow, genetic parameter

\section{INTRODUCTION}

In dairy cows, the pattern of milk ejection during milking influences the efficiency of the milking process and the udder health status of the cow. Several factors affect milk flow traits such as premilking treatment (Rasmussen et al., 1992; Bruckmaier and Blum, 1996), teat anatomy, parity number, lactation stage (Sandrucci et al., 2007), and genetic components. Genetic studies of milk flow traits are of great interest and milkability is often included as a breeding goal for dairy cattle (Groen et al., 1997). Milk flow traits can have a great effect on net profit (Sivarajasingam et al., 1984; Meyer and Burnside, 1987) and culling rate (Bagnato et al., 2003).

Dairy cow milkability influences not only labor costs, electricity use, and milking parlor costs (interest and depreciation), but also the health status of the cows and the overall milk production. In addition to udder preparation, milk flow patterns influence machine on time, as well as peak and average milk flow rates (Rasmussen et al., 1992; Hogeveen and Ouweltjes, 2003).

On a phenotypic level, high SCS values have been associated with both low peak milk flow rates and long overmilking phases (Tančin et al., 2007) and high maximum milk flow rates and shorter plateau phase duration (Sandrucci et al., 2005). Controversial results have also been reported on a genetic level, where high SCS values have been found to be generally associated 
with faster milking (Lund et al., 1994; Boettcher et al., 1998; Zwald et al., 2005; Samoré et al., 2010). Although Rupp and Boichard (1999) reported a similar correlation between milking speed and SCS values, they found that the correlation between milking speed and the incidence of clinical mastitis was not significant. In contrast, Wiggans et al. (2007) reported correlation values between EBV for SCS and milking speed between -0.14 and -0.40 for different reliability levels and associated faster milking with lower SCS values. Samoré and Groen (2006) detected a nonlinear relationship between bulls' EBV, through the association of average SCS with classes of milking speed EBV in Italian Holsteins, although the correlation value between EBV (0.07) showed evidence of a small but unfavorable relationship.

Bimodality (BIM) of milk flow; that is, delayed milk ejection at the start of milking, is one of the most interesting variables measurable with a milkometer. Bimodality, which is associated with premilking delay time and teat preparation (Sandrucci et al., 2007; Ambord and Bruckmaier, 2009), has a negative effect on milking efficiency, causing increased machine time (Bruckmaier and Blum, 1996) and modified milk flow parameters (Sandrucci et al., 2007). In addition, BIM can affect udder health and teat conditions (Rasmussen, 2004). On a phenotypic level, BIM is associated with a shorter plateau phase duration and longer ascending and decreasing times; both traits are associated with higher SCC and unfavorable udder health conditions (Sandrucci et al., 2007; Tamburini et al., 2010). To date, analyses of BIM have only been conducted on a phenotypic level, and, to the best of our knowledge, no genetic estimates for BIM have been reported in the literature. Estimates of genetic parameters and genetic relationships of BIM with other traits under selection are needed to evaluate the inclusion of BIM within selection criteria. Udder type is included in the Italian Holstein-Friesian economic index through a composite index for udder conformation (Interbull, 1996) with an overall weight of $13 \%$ (Biffani et al., 2002). Although udder conformation directly affects milk flow patterns, the majority of studies have only investigated the correlations of this parameter with milking speed and milk flow patterns (Blake and McDaniel, 1978; Capote et al., 2006). To the best of our knowledge, no previous studies have evaluated the genetic correlation between BIM and udder type traits.

The aim of this study was to investigate milk flow traits in Italian Holstein-Friesian cows, with a special emphasis on BIM, using objective data measured with a milkometer. The following objectives will be addressed: (1) estimation of the genetic parameters of milk flow traits measured using a lactometer; (2) estimation of the genetic relationship between milk flow traits, milk production, udder function, and udder conformation; and (3) evaluation of genetic correlations with BIM to determine its potential usefulness as a trait associated with milk flow, milk production, and udder health in selection strategies.

\section{MATERIALS AND METHODS}

\section{Experimental Design}

Between 2001 and 2007, a total of 4,007 milk flow records from 3,925 Italian Holstein-Friesian cows were collected from 133 dairy herds. Milk flow traits were collected using a portable milkometer (LactoCorder, WMB AG, Balgach, Switzerland). Milk flow was evaluated over 5 measurements (Figure 1). Traits considered were as follows: (1) ascending time (AT), defined as the time between attainment of a milk flow rate of $>0.5$ $\mathrm{kg} / \mathrm{min}$ and the time of plateau (TP); (2) the TP is the period during which steady milk flow occurs; (3) decreasing time (DT) is defined as the period from the end of TP (i.e., declining flow rates) until milk flow is $<0.2 \mathrm{~kg} / \mathrm{min}$; (4) the total milking time (TMT) is the sum of these periods; and (5) the maximum flow rate (MMF). Data was recorded by the milkometer every $0.7 \mathrm{~s}$ and saved at intervals of $2.8 \mathrm{~s}$ (WBM, 2005). The presence of BIM was recorded as either 1 (bimodal flow) or 0 (normal flow). Data were generally collected only once per cow and (the few) repeated records were excluded from subsequent analyses.

Milk yield (MY) was recorded together with milk flow data, and SCC was collected during regular milk recordings and the value recorded on the nearest testday was used. Because routine milk recording occurs every $28 \mathrm{~d}$, the maximum distance between flow and

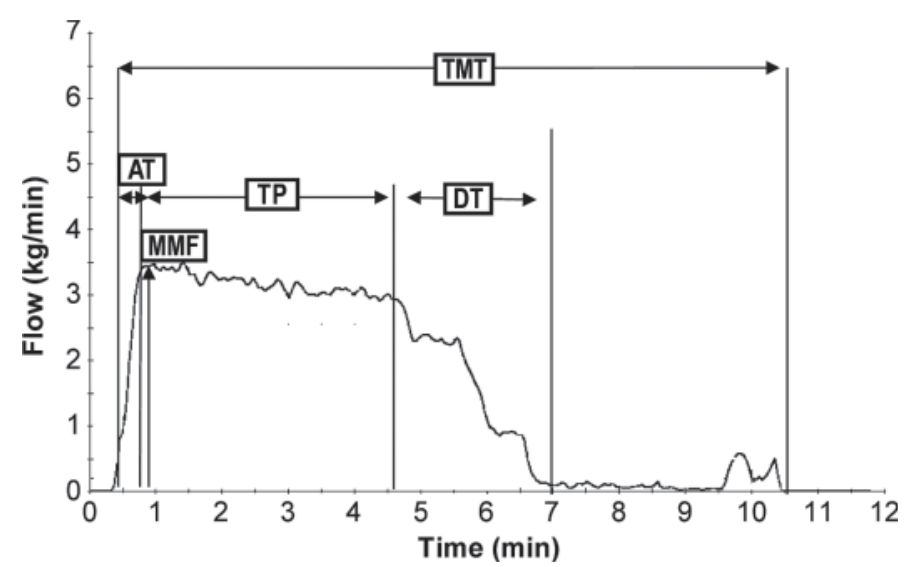

Figure 1. Graphical presentation of milk flow traits. AT $=$ ascending time; $\mathrm{TP}=$ time of plateau; $\mathrm{DT}=$ decreasing time; $\mathrm{MMF}=$ maximum milk flow; and TMT $=$ total milking time. 
Table 1. Descriptions, abbreviations, and means (SD) of udder linear type traits ${ }^{1}$

\begin{tabular}{|c|c|c|c|c|}
\hline Trait & $\begin{array}{l}\text { Description } \\
\text { of trait }\end{array}$ & \multicolumn{3}{|c|}{ Mean (SD) } \\
\hline Rear udder height & $1=$ low to $50=$ high attachment & $27.18(5.56)$ & $27.26(5.55)$ & $27.02(5.57)$ \\
\hline Rear udder width & $1=$ narrow to $50=$ wide attachment & $29.21(5.80)$ & $29.33(5.81)$ & $28.97(5.78)$ \\
\hline Ligament & $1=$ weak to $50=$ strong cleft & $29.75(6.28)$ & $29.82(6.15)$ & $29.63(6.52)$ \\
\hline Teat length & $1=$ short to $50=$ long teats & $22.78(7.08)$ & $22.90(6.99)$ & $22.55(7.24)$ \\
\hline
\end{tabular}

${ }^{1}$ Included 2,886 records in the complete data set, 1,910 normal flow records (no bimodality detected), and 976 bimodal flow records (bimodality detected).

SCC data was $14 \mathrm{~d}$. The SCC values were transformed into SCS values according to Wiggans and Shook (1987).

Udder type traits considered in this analysis (see Table 1) were collected on primiparous cows by classifiers from the Italian National Breeders Association of Holstein-Friesian (ANAFI). The udder traits were fore udder attachment (FUA), rear udder height (RUH), rear udder width (RUW), ligament (LIG), udder depth (UDD), udder balance (UDB), teat placement (TPL), and teat length (TLE).

Records with missing data on milk production or milk flow traits and records with inconsistent flow parameters were discarded from the analysis. A minimum of 2 records for each level of fixed effects included in the analysis model was required. Only records containing all traits were considered and the final edited data set included 2,886 records. Pedigree information was extracted from the national herd book of the Italian Holstein-Friesian breed and included 5 generations of ancestors. The cows included in this data set were daughters of 1,026 sires and 3,274 dams.

\section{Data Analysis}

Three groups of animal models were used to estimate covariance components. Fixed effects included in the models were tested for statistical significance using the GLM procedure in SAS (SAS Inst. Inc., Cary, NC).

Production-Milk Flow Traits. A set of 28 bivariate linear animal models were fitted among MY, AT, TP, DT, TMT, MMF, and SCS as follows:

$$
\mathbf{Y}=\mathbf{X} \boldsymbol{\beta}+\mathbf{Z} \mathbf{u}+\mathbf{e}
$$

where $\mathbf{Y}$ corresponds to the matrix of phenotypic records for traits analyzed, $\mathbf{X}$ is the incidence matrix of fixed effects, $\mathbf{Z}$ is the incidence matrix for additive random animal effects, $\boldsymbol{\beta}$ and $\mathbf{u}$ are solution vectors for fixed and random effects, respectively, and e corresponds to the residuals vector. Fixed effects included in the model are as follows: parity (2 levels: first and successive lactations); herd clusters (5 levels); test year according to the season of test interaction (17 levels, seasons: January-March, April-June, July-September, October-December); DIM in 12 classes of $30 \mathrm{~d}$ each; BIM (2 levels); and milking time of day (2 levels; morning and afternoon). Random genetic $\left(0, \mathbf{A} \sigma^{2}\right)$ and residual $\left(0, \sigma^{2}\right)$ effects were assumed to be normally distributed, where $\mathbf{A}$ is the relationship matrix.. Herds were grouped into clusters using the FASTCLUST procedure in SAS (SAS Inst. Inc.), because the frequency of records per herd was low. Clusters were formed based on herd production levels.

Type-Milk Flow Traits. Genetic correlations between flow and functional traits were estimated using 2-trait animal models, and 56 analyses were performed between flow traits (MY, AT, TP, DT, TMT, MMF, and SCS) and functional traits (FUA, RUH, RUW, LIG, UDD, UDB, TPL, and TLE).

Fixed effects for milk production and milk flow traits were the same as described for the previous analysis. The effects of herd clusters ( 5 levels), evaluation year (10 levels), and classifier (15 levels) were specifically considered in the model of udder type traits.

Bimodality Trait. Bimodality was considered a categorical dependent variable. Heritability was estimated using a univariate threshold liability model with the following form:

$$
\lambda=\mathbf{X} \boldsymbol{\beta}+\mathbf{Z u}+\mathbf{e}
$$

where $\boldsymbol{\lambda}$ is the unobserved liabilities vector for the categorical BIM trait (assumed to exist as a normally distributed variable underlying the ordinal distribution); $\boldsymbol{\beta}$ is the systematic effects vector (defined below), $\mathbf{u}$ is the random animal effects vector; and $\mathbf{X}$ and $\mathbf{Z}$ are the corresponding incidence matrices. 
Bivariate threshold-linear animal models were fit to estimate correlations. Distributional assumptions for these models were as follows:

$$
\mathbf{u} \sim N(0, \mathbf{G} \otimes \mathbf{A})
$$

where $\mathbf{A}$ is an additive relationship matrix among individuals in the pedigree, and $\mathbf{G}$ represents the genetic (co)variance matrix for the bivariate models:

$$
\mathbf{G}=\left[\begin{array}{cc}
\sigma_{a 1}^{2} & \sigma_{a 12} \\
\sigma_{a 21} & \sigma_{a 2}^{2}
\end{array}\right] .
$$

Residuals were assumed to be uncorrelated, with a mean of 0 and a variance of $\mathbf{R}$, where $\mathrm{I}$ is the identity matrix:

$$
\mathbf{e} \sim N(0, \mathbf{R} \otimes \mathrm{I}) .
$$

Variances were forced to be equal to 1 for threshold analysis, so that for bivariate threshold-linear models:

$$
\mathbf{R}=\left[\begin{array}{cc}
1 & \sigma_{e 12} \\
\sigma_{e 21} & \sigma_{e 2}^{2}
\end{array}\right],
$$

where the residual variance for a linear trait is $\sigma_{e 2}^{2}$, and the relative covariances are $\sigma_{12}$ and $\sigma_{21}$.

Fixed effects in this analysis included parity number (2 levels, first and successive lactation), herd clusters (5 levels), interaction year and season (17 levels), DIM in monthly periods (12 levels), and milking order (2 levels: morning and afternoon) for BIM, and were the same as described above for milk production and udder type traits.

The program VCE 6 (Neumaier and Groeneveld, 1998; Groeneveld et al., 2008), which is based on
REML, was used for linear model analyses, whereas threshold and bivariate linear-threshold models were analyzed using Thrgibbs1f90 (Tsuruta and Misztal, 2006). Single chains of 200,000 iterations were considered, with a burn-in period of 100,000 iterations. The values of parameters were sampled every 100 cycles to obtain the posterior means. Convergence for threshold and linear-threshold models was assessed visually from the trace plot. Inferences about parameters were based on the means of their respective distributions, obtained as output from the Postgibbsf90 programs (Tsuruta and Misztal, 2006).

\section{RESULTS AND DISCUSSION}

\section{Description of Milk Flow Traits}

Average MY was $14.61 \mathrm{~kg}$ per milking, with an SCS value of 3.45 (Table 2), in line with official data published annually by the Italian National Breeders Association of Holstein-Friesians. These values are similar to data reported in the literature for the same breed (Sandrucci et al., 2007). Average milk flow traits and associated standard deviations recorded in this study were comparable to previously reported values for Holstein-Friesian cows (Sandrucci et al., 2007). The average MY presented in this study was calculated over all DIM, but, as expected and as observed by Bruckmaier and Hilger (2001) and Sandrucci et al. (2007), MY decreased with lactation stage and increased with milking intervals in each lactation stage. Milk flow parameter averages are reported in Table 2 and do not differ substantially from values recorded for Brown Swiss cows (Gray et al., 2011). The slightly longer milking times measured in Holstein-Friesian compared with Brown Swiss cows, which are associated with longer DT and higher MMF, are the result of differences in average milk production between the 2 breeds.

The presence of BIM (Table 2) was reported in $33.8 \%$ of the total records (976 records), similar to the

Table 2. Number of records, and mean (SD) for traits in all records and for records reporting normal or bimodal milk flow

\begin{tabular}{lccc}
\hline & \multicolumn{3}{c}{ Mean (SD) } \\
\cline { 2 - 4 } & All & Normal & Bimodal \\
frait & records & flow & 976 \\
\hline Records (n) & 2,886 & 1,910 & $13.60(4.18)$ \\
Milk yield (kg) & $14.61(4.38)$ & $15.13(4.39)$ & $1.26(0.33)$ \\
Ascending time (min) & $0.86(0.44)$ & $0.66(0.33)$ & $1.46(1.17)$ \\
Time of plateau (min) & $2.18(1.60)$ & $2.55(1.66)$ & $2.80(1.21)$ \\
Decreasing time (min) & $2.88(1.37)$ & $2.92(1.44)$ & $7.07(2.06)$ \\
Total milking time (min) & $7.52(2.38)$ & $3.55(2.50)$ & $4.12(1.14)$ \\
Maximum milk flow (kg/min) & $3.85(1.1)$ & $3.71(1.12)$ & $3.54(1.95)$ \\
SCS & $3.45(2.00)$ & $3.40(2.01)$ & \\
\hline
\end{tabular}


Table 3. Averaged heritability values (diagonal), and genetic (above) and phenotypic (below) correlations between traits collected with the milkometer and SCS (SE in parentheses)

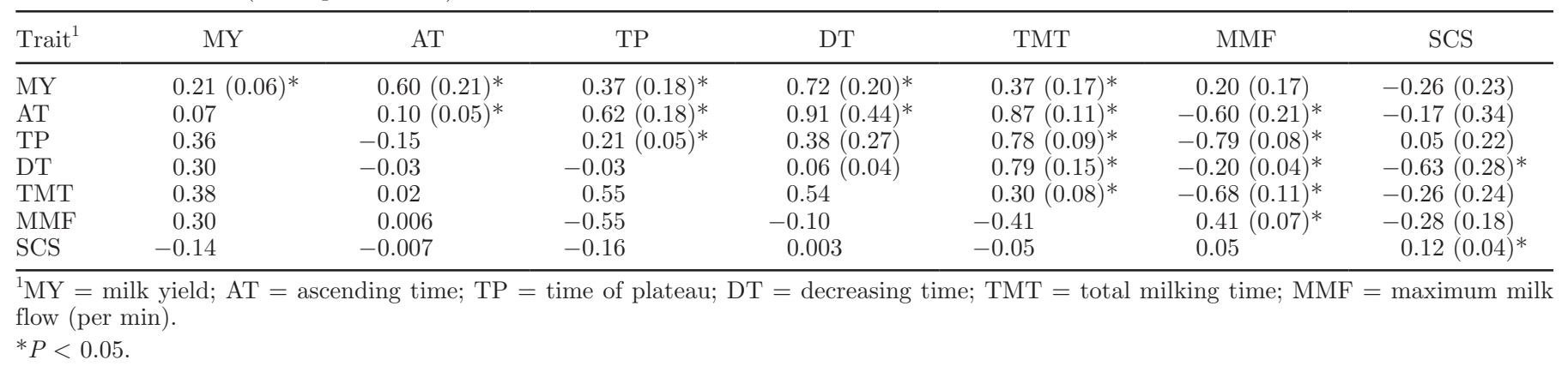

prevalence of BIM (35.1\%) reported in literature for the same breed (Sandrucci et al., 2007). The percentage of bimodal curves (data not shown) increased throughout lactation $(<150 \mathrm{DIM}=27 \%$ and $>150 \mathrm{DIM}=39 \%)$, as previously noted by Sandrucci et al. (2007). A milk flow presenting BIM can be attributed to 2 processes: the delayed ejection of the alveolar milk fraction resulting in a reduction in udder filling throughout milking (Bruckmaier and Hilger, 2001) or the progressive decrease of cisternal milk with increased DIM (Caja et al., 2004). Regardless, bimodal milk flow is associated with a need for prolonged udder stimulation in late lactation cows (Ambord and Bruckmaier, 2009), resulting in increased manual work.

Bimodal milking resulted, on average, in slightly lower milk production, longer AT, shorter TP, shorter DT, and slightly shorter TMT, compared with nonbimodal records (Table 2), similar to values reported by Sandrucci et al. (2007). Nevertheless, differences in the data presented here were, in general, not statistically significant (data not shown). Values of SCS (Table 2) were not statistically different between BIM and normal flow, although measured values were slightly higher for BIM $=1$. Maximum milk flow was higher in bimodal than in normal milk flow curves (4.12 vs. 3.71, respectively).

\section{Milk Flow Traits and Production}

The heritability value estimated for MY single controls was 0.21 (SE 0.06; Table 3), slightly smaller than the official 305-d MY value of 0.30 used for EBV prediction in Italy and previous estimates of this parameter in the same breed (Muir et al., 2007). Similar heritability values of 0.20 and 0.22 were reported by Guler et al. (2009) in a sample of 1,267 records for morning and afternoon milking, respectively. As expected, milk yield was positively correlated (Table 3 ) with TMT (0.37) and with all measures of milk ejection time, such as AT (0.60), TP (0.37), and DT (0.72).

\section{Milk Flow Traits}

With the exception of DT, which had a heritability value of only 0.06 , moderate heritability values were found for most milk flow traits (Table 3), ranging from 0.10 (AT) to 0.41 (MMF). Heritability values reported here for MMF (0.41) and TMT (0.38) are similar to those reported by Gade et al. (2006) and estimated for Brown Swiss cows (Gray et al., 2011).

High correlation estimates (Table 3) were found between all measures of time of milk flow parameters (AT, $\mathrm{TP}$, and DT) with values ranging from 0.62 (between $\mathrm{AT}$ and TP) to 0.91 (between DT and AT). In addition, higher MMF was correlated with shorter AT, TP, DT, and TMT; thus, higher MMF was associated with a more efficient milking. This correlation, together with the moderate heritability value estimated for MMF (0.41), indicates that it may be possible to select for this trait to reduce milking time and associated milking costs.

Milking traits can be measured objectively, using either a chronometer or milkometer (Sandrucci et al., 2007), or subjectively, based on information given by farmers (Meyer and Burnside, 1987). Currently, the Italian Holstein-Friesian selection index does not consider milk flow traits. Bulls' genetic evaluations for milkability are obtained from information given subjectively by farmers, who are asked to identify cows that are slower in milking compared with the herd average. No information on faster milking cows, milking speed scores, or precise timing measures is recorded on a population level for Italian Holstein Friesians. Therefore, objective data collected using a milkometer, together with the genetic parameters estimated in this study, represent an opportunity to evaluate the possible implementation of selection for milkability based on objective measures in the Italian Holstein-Friesian.

\section{Milk Flow and Udder Type Traits}

Genetic correlations between milk flow measurements and udder type traits were calculated for all 
trait combinations (Table 4). However, our discussion will be limited to only statistically significant values based on standard error estimates. The DT trait was found to have the highest genetic correlations with RUH (0.92), RUW (0.85), and TPL (0.73). In addition, milk production was positively associated with RUH, RUW, LIG, and TPL, with genetic correlation values ranging from 0.61 to 0.93 , in agreement with results reported for Italian Brown Swiss cows (Samoré et al., 2010). In particular, larger udders (higher RUH and larger RUW) with stronger attachments (stronger LIG) are positively associated with higher milk production. Although the genetic correlations obtained in this study should be confirmed with a larger data set, they suggest that udder conformation also determines the aptitude of cows to milking, and that indirect selection using udder type traits would contribute to the genetic improvement of milk flow traits.

\section{SCC}

The estimated heritability value for SCS (Table 3) obtained in this study was 0.12 , similar to previously reported values for Italian Holsteins (Samoré, 2003; Muir et al., 2007). An unfavorable, positive genetic correlation between SCS and MY has often been reported in the literature (for review see Mrode and Swanson, 1996), indicating an association between higher milk production and greater SCS values. In this study, the correlation value was not significantly different from zero $(-0.26 \pm 0.23)$ and, therefore, did not support either the unfavorable correlations of the literature or the favorable relationship reported for the Italian Holstein-Friesians breed, based on test-day model analyses (Samoré, 2003; Samoré et al., 2008).

The direction of genetic correlation between SCS and udder type traits (Table 4) found in this study is in line with previously reported estimates for the same breed (Samoré and Groen, 2006), although with larger values and, sometimes, larger standard errors.

Genetic correlations between SCS and milk flow were calculated for all trait combinations (Table 3), and a mix of different results was derived. Faster milking (i.e., shorter DT) was associated with increased SCS values, whereas correlations with the other flow traits were not different from zero $(P>0.05)$. In the literature, according to Gray et al. (2011), the lactation average SCS of Brown Swiss cows is associated with shorter TP, higher MMF, and longer DT. A negative correlation $(-0.40)$ was reported by Wiggans et al. (2007) for Brown Swiss cows between a subjectively scored milking speed and SCS, but positive values were reported for Holstein cows by Rupp and Boichard (1999) and Zwald et al. (2005), based on subjectively scored milking speed and electronically recorded milking duration, respectively. In conclusion, the inconsistent estimates of the genetic association between SCS and milk flow traits can also be explained by the existence of a nonlinear relation between milking traits and udder diseases, as suggested by several studies (Luttinen and Juga, 1997; Zwald et al., 2005; Samoré and Groen, 2006), indicating that intermediate flow rates are optimal with respect to susceptibility to mastitis.

\section{Bimodality}

A Gibbs sampling algorithm was employed to obtain the heritability value of BIM and its genetic correlations with milk flow traits and SCS. The posterior density for these estimates is shown in Figure 2. Plots of these posterior densities indicate sufficient support for the estimates of these parameters, with the exception of AT and DT, where the distributions were highly skewed, denoting poor convergence and hampering interpreta-

Table 4. Genetic correlations between udder type traits and flow traits measured using a milkometer (milk production and milk flow traits) and SCS (SE in parentheses)

\begin{tabular}{|c|c|c|c|c|c|c|c|c|}
\hline \multirow{2}{*}{$\begin{array}{l}\text { Flow } \\
\text { trait }^{1}\end{array}$} & \multicolumn{8}{|c|}{ Type trait ${ }^{2}$} \\
\hline & FUA & RUH & RUW & LIG & UDD & UDB & TPL & TLE \\
\hline $\mathrm{AT}$ & $-0.21(0.31)$ & $-0.23(0.29)$ & $0.19(0.25)$ & $-0.39(0.35)$ & $0.21(0.41)$ & $-0.05(0.35)$ & $0.28(0.33)$ & $0.22(0.29)$ \\
\hline $\mathrm{TP}$ & $-0.23(0.18)$ & $0.26(0.21)$ & $-0.01(0.20)$ & $0.14(0.24)$ & $-0.23(0.22)$ & $-0.20(0.22)$ & $0.12(0.21)$ & $0.16(0.19)$ \\
\hline DT & $0.58(0.39)$ & $0.92(0.22)^{*}$ & $0.85(0.23)^{*}$ & $0.44(0.29)$ & $-0.25(0.36)$ & $-0.30(0.35)$ & $0.73(0.36)^{*}$ & $0.40(0.33)$ \\
\hline TMT & $-0.14(0.18)$ & $0.31(0.22)$ & $-0.03(0.18)$ & $-0.002(0.22)$ & $-0.15(0.23)$ & $-0.29(0.23)$ & $0.44(0.21)$ & $0.000(0.19)$ \\
\hline
\end{tabular}

${ }^{1} \mathrm{MY}=$ milk yield; $\mathrm{AT}=$ ascending time; $\mathrm{TP}=$ time of plateau; $\mathrm{DT}=$ decreasing time; $\mathrm{TMT}=$ total milking time; $\mathrm{MMF}=$ maximum milk flow (per min).

${ }^{2} \mathrm{FUA}=$ fore udder attachment; RUH = rear udder height; RUW = rear udder width; LIG = ligament; UDD = udder depth; UDB = udder balance; $\mathrm{TPL}=$ teat placement; TLE $=$ teat length.

$* P<0.05$. 

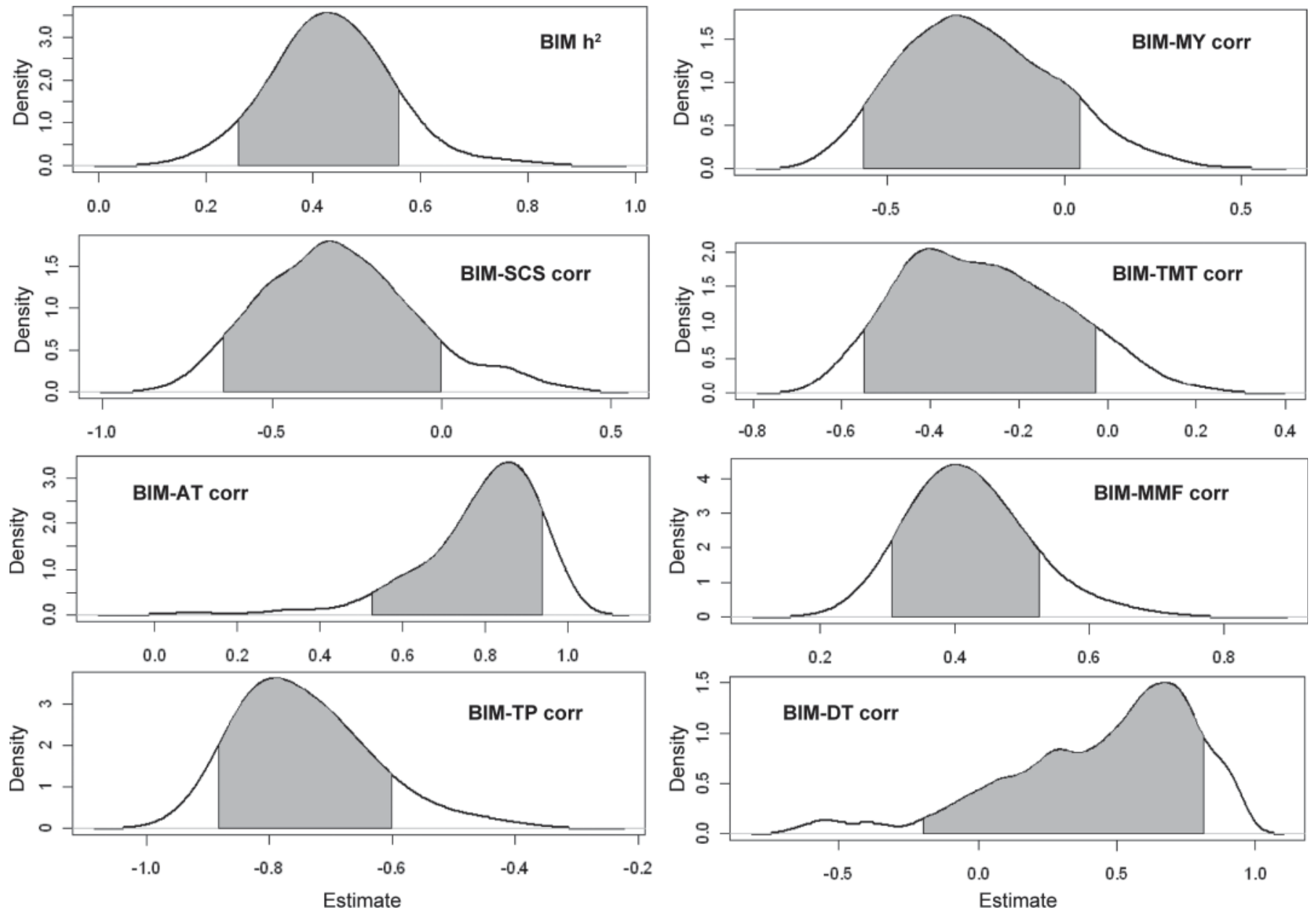

Figure 2. Posterior distributions of estimates of the heritability $\left(\mathrm{h}^{2}\right)$ of bimodality (BIM) and of genetic correlations (corr) of BIM with milk yield (MY), ascending time (AT), time of plateau (TP), decreasing time (DT), total milking time (TMT), maximum milk flow (MMF), and SCS. Highest $95 \%$ confidence regions (HCR) are represented as shadowed regions. The density of posterior distribution is shown on the ordinate axes and estimates of $\mathrm{h}^{2}$ or corr are shown on the axes of abscissa.

tion of the results. The reasons for this could arise from the small data set sampled and the low heritability values of the 2 traits (Table 3). A longer chain of the Gibbs sampler (data not shown) did not provide better convergence and the results for these parameters should be re-evaluated using a larger data set. A value of 0.43 (highest 95\% confidence region: $0.26,0.60$ ), was estimated for the heritability of BIM, indicating a sizable genetic component underlying this trait. The presence of BIM was negatively associated with MY and thus an increase in milk production might result in altered milk flow patterns. Shorter milking times (TMT and TP) and greater peak milk levels (MMF) were genetically correlated with more frequent bimodal flow, indicating that faster milk release would result in an increase in bimodal patterns. This is in agreement with evidence from the literature suggesting that selection for longer TP (within the same TMT) would reduce the presence of BIM and thus the need for longer udder prestimulation periods (Zucali et al., 2009; Gray et al., 2011).

Although BIM is believed to be associated with udder health because of its similarity to overmilking and its association with SCC (Bruckmaier et al., 1995; Sandrucci et al., 2007), our results do not support this claim. The posterior distribution of genetic correlations between SCS and BIM is centered at -0.30 (highest 95\% confidence region: $-0.64,-0.01$ ), associating BIM with a reduction in SCS. The negative correlation estimated in this study between BIM and SCS could also depend on other factors, such as premilking treatments not completely accounted for by herd cluster effects, and thus require further investigation. Similarly, the effect of BIM on milk flow patterns may depend on several environmental factors and on pathogens involved, thereby complicating the genetic correlation between BIM and SCS. Finally, the hypothesis that a nonlinear 
relationship exists between SCS and milkability (Luttinen and Juga, 1997; Zwald et al., 2005; Samoré and Groen, 2006) may explain results found in this study.

\section{CONCLUSIONS}

The genetic association of BIM with milk flow traits was investigated. Estimated genetic parameters suggested the potential use of BIM in genetic selection to improve milkability of dairy cattle, although its association with certain milk flow traits and SCS warrants further research. Improved milkability may also be attained by indirect selection for udder conformation.

\section{ACKNOWLEDGMENTS}

We thank Marco Laurenti (SATA technician) of the Association of Breeders of Milano and Lodi (Milano, Italy) for recording the data used in this research. The Italian National Breeders Association of HolsteinFriesian (ANAFI, Cremona, Italy) is acknowledged for collecting and providing type and genealogical data.

\section{REFERENCES}

Ambord, S., and R. M. Bruckmaier. 2009. Milk flow-controlled changes of pulsation ratio and pulsation rate affect milking characteristics in dairy cows. J. Dairy Res. 76:272-277.

Bagnato, A., A. Rossoni, C. Maltecca, D. Vigo, and S. Ghiroldi. 2003. Milk emission in different parities in Italian Brown Swiss cattle. Ital. J. Anim. Sci. 2(Suppl. 1):46-48.

Biffani, S., A. B. Samoré, and F. Canavesi. 2002. PFT: The new selection index for the Italian Holstein. Interbull Bull. 29:142-143.

Blake, R. W., and B. T. McDaniel. 1978. Relationships among rates of milk flow, machine time, udder conformation, and management aspects of milking efficiency: A review. J. Dairy Sci. 61:363-378.

Boettcher, P. J., J. C. M. Dekkers, and B. W. Kolstad. 1998. Development of an udder health index for sire selection based on somatic cell score, udder conformation, and milking speed. J. Dairy Sci. 81:1157-1168.

Bruckmaier, R. M., and J. W. Blum. 1996. Simultaneous recording of oxytocin release, milk ejection and milk flow during milking of dairy cows with or without prestimulation. J. Dairy Res. 63:201208.

Bruckmaier, R. M., and M. Hilger. 2001. Milk ejection in dairy cows at different degrees of udder filling. J. Dairy Res. 68:369-376.

Bruckmaier, R. M., E. Rothenanger, and J. M. Blum. 1995. Milking characteristics in dairy cows of different farms and during the course of lactation. J. Anim. Breed. Genet. 112:293-302.

Caja, G., M. Ayadi, and C. H. Knight. 2004. Changes in cisternal compartment based on stage of lactation and time since milk ejection in the udder of dairy cows. J. Dairy Sci. 87:2409-2415.

Capote, J., A. Argüello, N. Castro, J. L. López, and G. Caja. 2006. Correlations between udder morphology, milk yield, and milking ability with different milking frequencies in dairy goats. J. Dairy Sci. 89:2076-2079.

Gade, S., E. Stamer, W. Jungle, and E. Kalm. 2006. Estimates of genetic parameters for milkability from automatic milking. Livest. Sci. 104:135-146.

Gray, K. A., F. Vacirca, A. Bagnato, A. B. Samoré, A. Rossoni, and C. Maltecca. 2011. Genetic evaluations for measures of the milk flow curve in the Italian Brown Swiss. J. Dairy Sci. 94:960-970.
Groen, A. F., T. Steine, J. J. Colleau, J. Pedersen, J. Pribyl, and N. Reinsch. 1997. Economic values in dairy cattle breeding, with special reference to functional traits. Report of an EAAP working group. Livest. Prod. Sci. 49:1-21.

Groeneveld, E., M. Kovâc, and N. Mielenz. 2008. VCE User's Guide and Reference Manual Version 6.0. Institute of Farm Animal Genetics, Mariensee, Germany.

Guler, O., M. Yanar, R. Aydin, B. Bayram, U. Dogru, and S. Kopuzdu. 2009. Genetic and environmental parameters of milkability traits in Holstein-Friesian cows. J. Anim. Vet. Adv. 8:143-147.

Hogeveen, H., and W. Ouweltjes. 2003. Sensors and management support in high-technology milking. J. Anim. Sci. 81(Suppl. 3):1-10.

Interbull. 1996. Sire evaluation procedures for nondairy-production and growth and beef production traits practised in various countries. Interbull Bull. 13:83-89.

Lund, T., F. Miglior, J. C. M. Dekkers, and E. B. Burnside. 1994 Genetic relationships between clinical mastitis, somatic cell count, and udder conformation in Danish Holsteins. Livest. Prod. Sci. $39: 243-251$.

Luttinen, A., and J. Juga. 1997. Genetic relationships between milk yield, somatic cell count, mastitis, milkability and leakage in Finnish dairy cattle populations. Proc. Int. Workshop Genetic Improvement of Functional Traits in cattle (GIFT)-health. Interbull Bull. 15:78-83. Interbull, Uppsala, Sweden.

Meyer, K., and B. Burnside. 1987. Scope for a subjective assessment of milking speed. J. Dairy Sci. 70:1061-1068.

Mrode, R. A., and G. J. T. Swanson. 1996. Genetic and statistical properties of somatic cell count and its suitability as an indirect means of reducing the incidence of mastitis in dairy cattle. Anim. Breed. Abstr. 64:847-857.

Muir, B. L., G. Kistemaker, and F. Canavesi. 2007. Genetic parameters for a multiple-trait multiple-lactation random regression testday model in Italian Holsteins. J. Dairy Sci. 90:1564-1574.

Neumaier, A., and E. Groeneveld. 1998. Restricted maximum likelihood estimation of covariances in sparse linear models. Genet. Sel. Evol. 1:41-62.

Rasmussen, M. D. 2004. Overmilking and teat condition. Pages 169175 in Proc. 43rd Annual Meeting of the National Mastitis Council. Natl. Mastitis Counc., Verona, WI.

Rasmussen, M. D., E. S. Frimer, D. M. Galton, and L. G. Peterson 1992. The influence of premilking teat preparation and attachment delay, on milk yield and milking performance. J. Dairy Sci $75: 2131-2141$.

Rupp, R., and D. Boichard. 1999. Genetic parameters for clinical mastitis, somatic cell score, production, udder type traits, and milking ease in first lactation Holsteins. J. Dairy Sci. 82:2198-2204.

Samoré, A. B. 2003. Genetic aspects of somatic cell count in the Italian Holstein-Friesian population. PhD Thesis. Wageningen University, Wageningen, the Netherlands.

Samoré, A. B., and A. F. Groen. 2006. Proposal of an udder health genetic index for the Italian Holstein-Friesian based on first lactation data. Ital. J. Anim. Sci. 5:359-370.

Samoré, A. B., A. F. Groen, P. J. Boettcher, J. Jamrozik, F. Canavesi, and A. Bagnato. 2008. Genetic correlation patterns between somatic cell count and protein yield in the Italian Holstein-Friesian population. J. Dairy Sci. 91:4013-4021.

Samoré, A. B., R. Rizzi, A. Rossoni, and A. Bagnato. 2010. Genetic parameters for functional longevity, type traits, SCS, milk flow and production in the Italian Brown Swiss. Ital. J. Anim. Sci. 9:145-152.

Samoré, A. B., M. del P. Schneider, F. Canavesi, A. Bagnato, and A. F. Groen. 2003. Relationship between somatic cell count and functional longevity assessed using survival analysis in Italian HolsteinFriesian cows. Livest. Prod. Sci. 80:211-220.

Sandrucci, A., L. Bava, A. Tamburini, and L. Zanini. 2005. Milking procedures, milk flow curves and somatic cell count in dairy cows. Ital. J. Anim. Sci. 4(Suppl. 2):215-217.

Sandrucci, A., A. Tamburini, L. Bava, and M. Zucali. 2007. Factors affecting milk flow traits in dairy cows: Results of a field study. J. Dairy Sci. 90:1159-1167. 
Sivarajasingam, S., E. B. Burnside, J. W. Wilton, W. C. Pfeiffer, and D. G. Grieve. 1984. Ranking dairy sires by a linear programming dairy farm model. J. Dairy Sci. 67:3015-3024.

Tamburini, A., L. Bava, R. Piccinini, A. Zecconi, M. Zucali, and A. Sandrucci. 2010. Milk emission and udder health status in primiparous dairy cows during lactation. J. Dairy Res. 77:13-19.

Tančin, V., A. H. Ipema, and P. Hogewefer. 2007. Interaction of somatic cell count and quarter milk flow patterns. J. Dairy Sci. 90:2223-2228.

Tsuruta, S., and I. Misztal. 2006. THRGIBBS1F90 for estimation of variance components with threshold-linear models. Commun. 27-31 in Proc. 8th World Congr. Genet. Appl. Livest. Prod., Belo Horizonte, Brazil.

WBM. 2005. System LactoCorder. The innovation for official milk recording. Operating instructions. Werkzeug-, Maschinen-, Apparatebau AG Balgach, Switzerland. Accessed April 12, 2011. http://www.lactocorder.ch.
Wiggans, G. R., and G. E. Shook. 1987. A lactation measure of somatic cell count. J. Dairy Sci. 70:2666-2672.

Wiggans, G. R., L. L. M. Thornton, R. R. Neitzel, and N. Gengler. 2007. Short communication: Genetic evaluation of milking speed for Brown Swiss dairy cattle in the United States. J. Dairy Sci. 90:1021-1023.

Zucali, M., L. Bava, A. Sandrucci, A. Tamburini, R. Piccinini, V. Daprà, M. Tonni, and A. Zecconi. 2009. Milk flow pattern, somatic cell count and teat apex score in primiparous dairy cows at the beginning of lactation. Ital. J. Anim. Sci. 8:103-111.

Zwald, N. R., K. A. Weigel, Y. M. Chang, R. D. Welper, and J. S. Clay. 2005. Genetic evaluation of dairy sires for milking duration using electronically recorded milking times of their daughters. J. Dairy Sci. 88:1192-1198. 